\section{Quality Changes in Asparagus Spears Stored in a Flow-through CA System or in Consumer Packages}

\author{
Lawford Baxter ${ }^{1}$ and Luther Waters, Jr. \\ Department of Horticultural Sciences and Landscape Architecture, \\ University of Minnesota, St. Paul, MN 55108
}

\begin{abstract}
Additional index words. Asparagus officinalis, sugars, organic acid, protein, consumer packaging
\end{abstract}

Abstract. Asparagus spears (Asparagus officinalis L.) stored 28 days at 2C in air, a flow-through controlled-atmosphere (CA) system, or 14 days in polymeric film consumer packages were evaluated in respect to compositional and quality changes. CAstored spears retained more sugars, organic acids, and soluble proteins than spears stored in air. Spears stored in vented consumer packages had a useful life of $\mathbf{1 4}$ days, whereas those in nonvented packages started to break down after 8 days. Spears from vented packages lost more weight but retained more sugars and organic acids than those from nonvented packages.

Rapid cooling of asparagus spears and storage at near-freezing temperatures are used to commercially maintain asparagus quality. Early reports (Baker and Morris, 1936) indicate that modified atmospheres are beneficial in reducing postharvest asparagus deterioration. Controlled-atmosphere storage of asparagus prevented the development of off-flavor (Kenkars, 1965), water loss (King et al., 1986), toughening (Lougheed and Dewey, 1966), and chlorophyll loss (Wang et al., 1971). CA effects on vitamin C content in asparagus depend on the atmosphere composition (Weichmann, 1986). Despite limited commercial distribution of asparagus under CA, metabolic aspects of CA effects on asparagus tissue are not well-documented.

Asparagus packaging in gas-barrier films is another area that has not been fully explored. Work with other commodities has indicated that retail packaging using gas-barrier films has potential for maintaining quality and extending shelf-life (Ben-Yehoshua, 1985). Distribution of fresh vegetables in polymeric-film packages helps to maintain quality by a combination of atmosphere modification and reduced water loss (Gorini, 1987). This paper presents the results of

Received for publication 20 Dec. 1989. Paper no. 16,141 of the Scientific Journal Series, Univ. of Minnesota Agricultural Experiment Station. The cost of publishing this paper was defrayed in part by the payment of page charges. Under postal regulations, this paper therefore must be hereby marked advertisement solely to indicate this fact.

'Graduate Student.

${ }^{2}$ Professor studies examining changes in asparagus spears stored in air, flow-through CA, and consumer packages, spears at $2 \mathrm{C}$.
'Mary Washington' asparagus was grown using standard cultural practices at the Univ. of Minnesota's Sand Plain Experiment Station, Becker, MN. Spears were harvested early in the morning and immediately hydrocooled to $2 \pm 1 \mathrm{C}$ with a 200-ppm $\mathrm{NaOCl}$ solution. Uniformly sized spears (1.5 to 2.0 $\mathrm{cm}$ diameter $\times 20.0 \mathrm{~cm}$ long) were trimmed and three replications of $2000 \mathrm{~g}$ each were placed with the butts resting on a wet pad in each of two $69 \times 37 \times 37 \mathrm{~cm}(\mathrm{~L} \times \mathrm{W} \times$ $\mathrm{H})$ plexiglass cabinets that then were sealed. Glass beads in plastic bags placed in the chambers minimized the free volume and hastened rapid establishment of the atmosphere. A controlled atmosphere of $5 \% \pm$ $1 \% \mathrm{O}_{2}, 10 \% \pm 1 \% \mathrm{CO}_{2}$, balance $\mathrm{N}_{2}$ prepared by mixing commercially bottled gas from high pressure cylinders, was passed through a $\mathrm{KMnO}_{4}$ ethylene scrubber into one cabinet, This atmosphere was chosen based on recommended levels (Kader et al., 1985) and the results of preliminary experiments. A relative humidity of $\approx 92 \%$, measured with a Model RH-30-2 humidity sensor (Omega Engineering, Stamford, Conn.) was maintained by a combination of the wet pad and
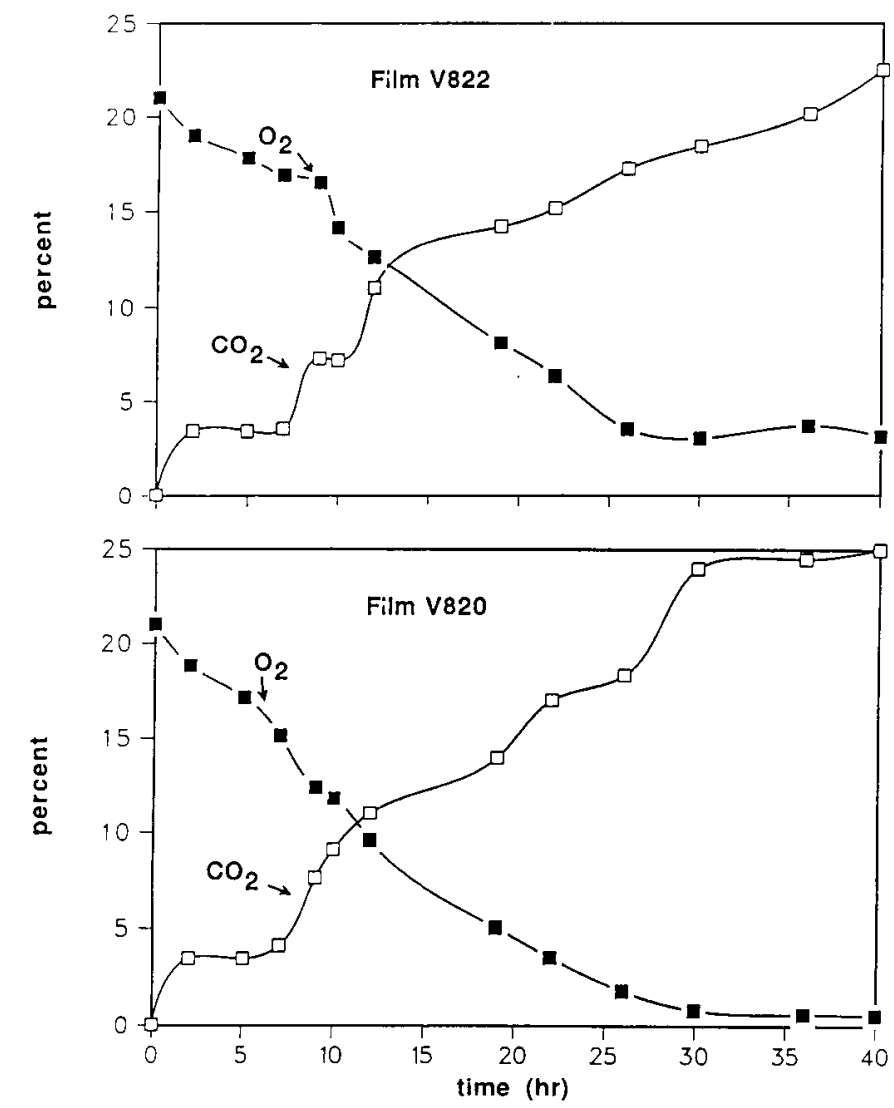

Fig. 1. Changes in $\mathrm{O}_{2}$ and $\mathrm{CO}_{2}$ levels in nonvented film packages containing $340 \mathrm{~g}$ of asparagus 

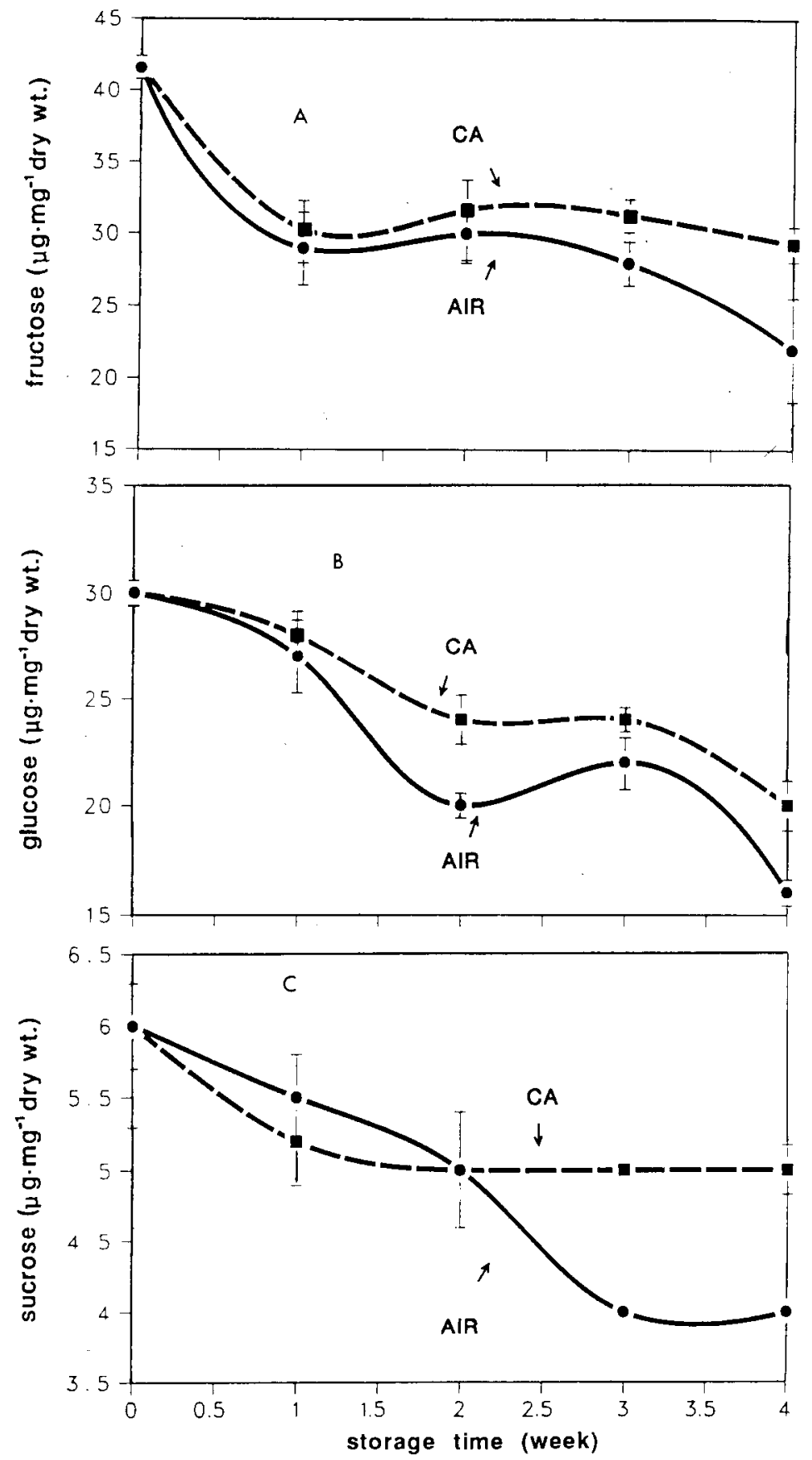

Fig. 2. Changes in sugar content of asparagus spears stored in air or $5 \% \mathrm{O}_{2}+10 \% \mathrm{CO}_{2}$. Points represent the means of nine observations. Vertical bars represent \pm SE and are not shown when smaller than symbols

by bubbling the gas through water before entry into the chamber. Flow meters, solenoid valves, timers, and a pressure-relief valve controlled gas flow into the cabinet and provided for one complete gas change each 16 h. Control spears were stored at the same temperature $(2 \mathrm{C})$, humidity $(\approx 92 \%)$, and gas turnover rate in air scrubbed free of ethylene. A slow gas flow-rate was necessary to prevent dehydration of the spears. Oxygen and $\mathrm{CO}_{2}$ levels were routinely measured with fyrite analyzers and were found to be within $\pm 1 \%$ of the desired concentrations. Steady state $\mathrm{O}_{2}$ and $\mathrm{CO}_{2}$ levels were established within 14 to $16 \mathrm{~h}$ after the cabinet was closed. The design was a randomized complete block evaporated to dryness. The residue was resuspended in $0.5 \mathrm{ml}$ of deionized water to which $1.5 \mathrm{ml}$ acetonitrile was later added. The sample was filtered through a $0.5-\mu \mathrm{m}$ filter and injected into a Waters Wisp 710B high performance liquid chromatography system fitted with a refractive index detector and a $3.9 \times 300 \mathrm{~mm}$ carbohydrate analysis column. The mobile phase was 85 acetonitrile : 15 water $(\mathrm{v} / \mathrm{v})$, delivered at a flow rate of $2 \mathrm{ml} \cdot \mathrm{min}^{-1}$. Fructose, glucose, and sucrose were quantified using an external standard of $1 \mathrm{mg}$ of each sugar/ml. Citric and malic acid were determined using enzyme kits (Boerhinger Mannheim Biochemical, 1986). For amino acid analysis, $1.0 \mathrm{~g}$ of the freeze-dried powders was extracted with 20.0 $\mathrm{ml}$ of $80 \%$ ethanol followed by centrifugation at $10,000 \times \mathrm{g}$ for $30 \mathrm{~min}$. The supernatant was collected and aliquots used for amino acid analysis with ninhydrin (Yemm and Cocking, 1955). The pellet remaining after centrifugation was extracted twice with $10 \mathrm{ml} 0.1 \mathrm{~N} \mathrm{NaOH}$ and centrifuged at $10,000 \times \mathrm{g}$ for $30 \mathrm{~min}$. The supernatant was collected and 5-ml aliquots used for soluble protein analysis according to Bradford (1976). Total $\mathrm{N}$ was determined on $100 \mathrm{mg}$ of the freeze-dried powder using the Kjeldahl method (Assn. of Official Anal. Chemists, $1975)$ and crude protein calculated as percent $\mathrm{N} \times 6.25$.

For the consumer packages, two polymeric films (V820 and V822; Cryovac, Duncan, S. C.) were made into packages 25 $\times 20 \times 3.5 \mathrm{~cm}(\mathrm{~L} \times \mathrm{W} \times \mathrm{H})$. Film V820 had $\mathrm{O}_{2}$ and $\mathrm{CO}_{2}$ transmission rates of (per $24 \mathrm{~h}) 0.2 \mathrm{ml} \cdot \mathrm{m}^{-2}$ and $1 \mathrm{ml} \cdot \mathrm{m}^{-2}$, respectively. The transmission rates for V822 were (per $24 \mathrm{~h}$ ) $2200 \mathrm{ml} \cdot \mathrm{m}^{-2}$ for $\mathrm{O}_{2}$ and 11,200 $\mathrm{ml} \cdot \mathrm{m}^{-2}$ for $\mathrm{CO}_{2}$ (film permeability measured at $21 \mathrm{C}, 1 \times 10^{5} \mathrm{~Pa}, 100 \% \mathrm{O}_{2}$, and $0 \% \mathrm{RH}$ by Cryovac). A 2-mm-diameter punch was used to perforate the packages so that either $0 \%, 1 \%, 2.5 \%, 5 \%$, or $7.5 \%$ of the total surface area of each package was ventilated. About $340 \mathrm{~g}$ of hydrocooled spears was placed in each package along with a wet paper pad to maintain the humidity. The packages were sealed with a Scotchpak pouch sealer (Kapak Corp., Bloomington, Minn.) and stored at 2 $\pm 1 \mathrm{C}$ for 14 days. Headspace gases within the packages were analyzed with Fyrite analyzers until $\mathrm{CO}_{2}$ and $\mathrm{O}_{2}$ concentrations leveled off (Fig. 1). Gas sampling was done through septa glued to the side of the packages. At the end of storage, all samples were weighed and sensory evaluation (Table 1) carried out using a three-member panel. Sugar and soluble protein were determined as described above. The experiment was a $2 \times 5$ factorial in a completely randomized design with four replications, each replication consisting of one package. Data analysis was by an analysis of variance procedure.

Flow-through CA study. Although the sugar and organic acid contents of both air-stored and CA spears declined during storage, both tended to remain higher in CA than in airstored spears (Figs. 2 and 3). Significant differences in sugar content generally occurred during the 3rd week of storage. Fructose de- 

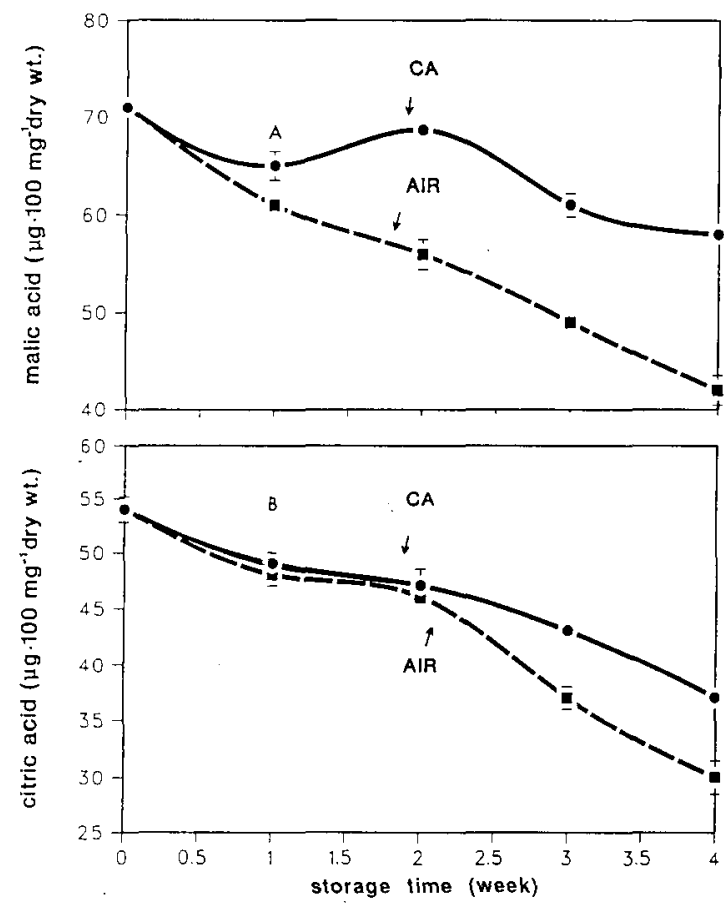

Fig. 3. Changes in malic acid (A) and citric acid (B) of asparagus spears stored in air or $5 \% \mathrm{O}_{2}+10 \% \mathrm{CO}_{2}$. Points represent the means of nine observations. Vertical bars represent \pm SE and are not shown when smaller than symbols.
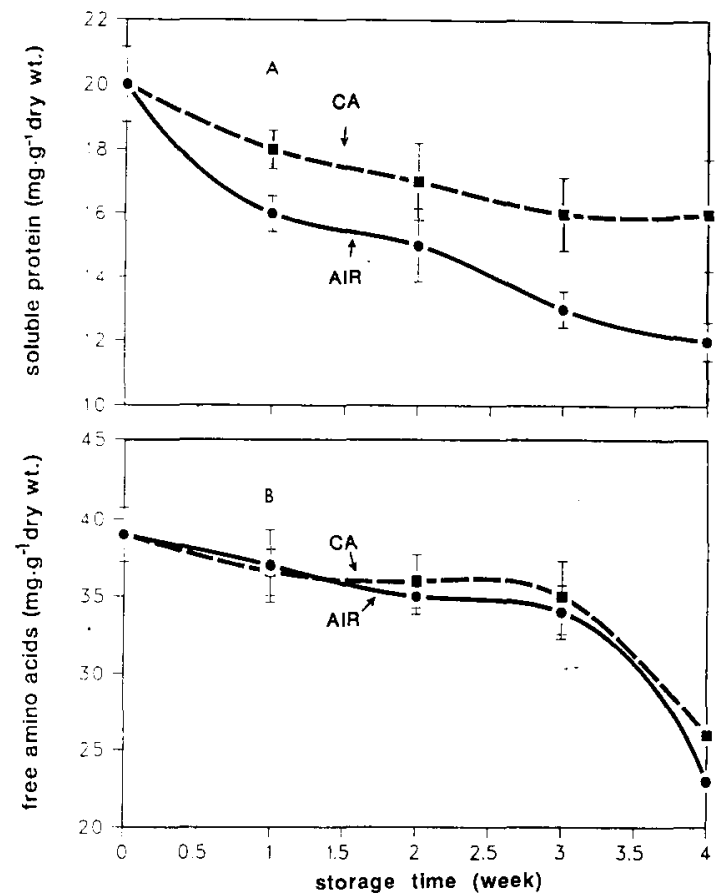

Fig. 4. Changes in soluble protein (A) and free amino acids (B) of asparagus spears stored in air or $5 \% \mathrm{Q}+10 \% \mathrm{CO}_{2}$. Points represent the means of nine observations. Vertical bars represent \pm SE and are not shown when smaller than symbols.

Table 1. Film type (V820 and V822) and degree of package venting effects on quality, weight loss, sugar, and protein content of asparagus spears stored 14 days at $2 \mathrm{C}$.

\begin{tabular}{|c|c|c|c|c|c|c|c|}
\hline Film type & $\begin{array}{c}\text { Venting } \\
(\%)\end{array}$ & $\begin{array}{c}\text { Color } \\
\text { (rating) }^{z}\end{array}$ & $\begin{array}{c}\text { Odor } \\
\text { (rating) }\end{array}$ & $\begin{array}{c}\text { Breakdown } \\
\text { (rating) }\end{array}$ & $\begin{array}{c}\mathrm{Wt} \\
\operatorname{loss}(\%)\end{array}$ & $\begin{array}{c}\text { Sugar } \\
\text { concn } \\
(\%)\end{array}$ & $\begin{array}{l}\text { Protein } \\
\text { concn }(\%)\end{array}$ \\
\hline \multirow[t]{5}{*}{ V820 } & 0 & 5 & 5 & 4 & 3 & 22.3 & 83 \\
\hline & 1 & 5 & 4 & 4 & 3 & 41.0 & 89 \\
\hline & 2.5 & 3 & 2 & 0 & 10 & 84.0 & 86 \\
\hline & 5 & 2 & 0 & 0 & 10 & 82.5 & 87 \\
\hline & 7 & 2 & 0 & 0 & 12 & 81.0 & 90 \\
\hline \multirow[t]{5}{*}{ V822 } & 0 & 5 & 5 & 4 & 2 & 32.0 & 87 \\
\hline & 1 & 5 & 3 & 4 & 4 & 63.5 & 93 \\
\hline & 2.5 & 4 & 0 & 0 & 5 & 85.0 & 94 \\
\hline & 5 & 3 & 0 & 0 & 7 & 84.0 & 96 \\
\hline & 7 & 2 & 0 & 0 & 7 & 84.0 & 94 \\
\hline Source & $\mathrm{df}$ & MS & MS & MS & MS & MS & MS \\
\hline Film type & 1 & $0.44^{\mathrm{NS}}$ & $4.8^{\mathrm{NS}}$ & $0.01^{\mathrm{NS}}$ & $13.2^{\mathrm{NS}}$ & $169.9^{*}$ & $357^{*}$ \\
\hline Venting & 4 & $15.78^{*}$ & $41.1^{*}$ & $39.8^{*}$ & $80.77^{*}$ & $5009.8^{*}$ & $62.8^{*}$ \\
\hline Film $\times$ vent & 4 & $0.40^{\mathrm{NS}}$ & $2.01^{\mathrm{NS}}$ & $0.01^{\mathrm{NS}}$ & $11.77^{\mathrm{NS}}$ & $157.0^{\mathrm{NS}}$ & $11.21^{*}$ \\
\hline Error & 30 & 0.06 & 0.09 & 0.01 & 0.42 & 6.1 & 3.20 \\
\hline
\end{tabular}

${ }^{\mathrm{z}}$ Scale $0=$ Color at harvest to $5=$ yellow to brown.

${ }^{\gamma}$ Scale $0=$ Normal odor to $5=$ highly objectionable odor.

${ }^{\mathrm{x}} \mathrm{S}$ cale $0=$ No breakdown to $5=$ severe breakdown.

Nonsignificant or significant at $P<0.05$, respectively.

clined most for air-stored spears, whereas sucrose declined most in CA-stored spears. Greater retention of sugars and organic acids in CA-stored compared to air-stored spears indicates a general impairment of glycolytic and tricarboxylic cycle reactions.

Beginning with the 1st storage week, significant differences $(P<0.05)$ were observed between the soluble protein content in air-stored and CA-stored spears (Fig. 4A), with CA-stored spears retaining more protein. Free amino acids declined about equally under both storage regimes (Fig. 4B). Expressed on a dry-weight basis, the crude protein content showed a slight increase for CA- and air-stored spears (data not shown), most likely due to carbohydrate loss through respiration and microbial decomposition, and is similar to results for leeks (Kurki, 1979). Microbial decomposition of the spears was most evident at the tips and occurred to a greater extent in air-stored than in CA-stored spears. Erwinia was identified as the causal agent. Oxygen concentrations in the range used have little effect on Erwinia rot, but high $\mathrm{CO}_{2}$ levels retarded development of bacterial soft rot (Lipton, 1965). CA-stored spears had tightly closed tips that may have offered some resistance to pathogen invasion. Asparagus spears with tightly closed tips are less susceptible to microbial decay than those with tips that are "feathered" (Lipton, 1968). Loss of protein and amino acids in CA- and air-stored spears is probably due to metabolic turnover of nitrogenous compounds within the tissue,

Consumer package study. Variable results were obtained from the consumer packaging study. When the packages were not ventilated, severe spear breakdown occurred, evidenced by sliminess of the tips and development of a putrid odor and browning (Table 1). Since there was no evidence of microbial growth, the putrid odor and general breakdown were probably due to anaerobic respiration, low $\mathrm{O}_{2}$, or high $\mathrm{CO}_{2}$ injury. Spear breakdown occurred only in nonvented packages; in some of these packages, $\mathrm{O}_{2}$ content was as low as $2 \%$ and $\mathrm{CO}_{2}$ content as high as $25 \%$ after $40 \mathrm{~h}$ of storage (Fig. 1). Spear quality was the best in packages with $2.5 \%$ and $5.0 \%$ of the surface area vented for V822 and V820, respectively. Although venting improved quality, weight loss was increased.

Sugar and soluble protein levels were also affected by the degree of package venting (Table 1). Retention of sugars and protein was lower in nonvented than in vented packages regardless of film type.

The use of $\mathrm{O}_{2} / \mathrm{CO}_{2} / \mathrm{H}_{2} \mathrm{O}$ barrier films has potential for $\mathrm{CA}$ packaging of perishable horticultural commodities. However, the films used in the present study were not effective in maintaining the fresh quality of the asparagus without venting. The low $\mathrm{O}_{2}$ and high $\mathrm{CO}_{2}$ levels of nonvented packages indicated that the gas-transmission properties of both films did not match the respiration rate of the asparagus. Recently, breathable 
films with permeability characteristics that can match the respiration rates of many vegetables have been developed (Antoon, 1989). It would be of interest to evaluate the quality of asparagus stored with these materials.

\section{Literature Cited}

Antoon, M.K. 1989. Process for producing uniaxial polyolefin/filler films for controlled atmosphere packaging. U.S. Patent 4,879,078.

Assn. of Official Analytical Chemists. 1975. Official methods of analysis. 12th ed. AOAC, Washington D.C.

Baker, J. and J.N. Morris. 1936. The storage of asparagus. Great Britain Dept. Sci. Ind. Res. Dept. Food Invest. Bd. p. 172.

Ben-Yehoshua, S. 1985. Individual seal-packaging of fruit and vegetables in plastic film-a new postharvest technique. HortScience 20(1):32-37.

Boerhinger Mannheim Biochemical. 1986. Methods of biochemical analysis and food analysis. Boerhinger Mannheim Biochemical, Indianapolis, Ind.

Bradford, M. 1976. A rapid and sensitive method for the quantitation of microgram quantities of protein using the principle of protein dye-binding. Anal. Biochem. 72:248-254.

Gorini, F. 1987. Market preparation methods and shelf life, p. 489-495. In: J. Weichmann (ed.). Postharvest physiology of vegetables. Marcel Dekker, N.Y.

Kader, A.A., R.F. Kasmire, F. Gordon Mitchell, M.S. Reid, N.F. Sommer, and J.F. Thompson. 1985. Postharvest technology of horticultural crops. Univ. of California Spec. Publ. no. 3311. p. 60.

Kenkars, E. 1965. Gross changes in asparagus stored in modified atmospheres. MS Thesis, Rutgers Univ., New Brunswick, N.J.

King, G.A., K.G. Henderson, and R.E. Lill. 1986. Asparagus: effect of controlled atmosphere storage on shelf-life of four cultivars. N.Z. J. Expt. Agr. 14:421-424.

Kurki, L. 1979. Leek quality changes in storage.
Acta Hort. 93:85-90.

Lipton, W.J. 1965. Postharvest responses of asparagus spears to high carbon dioxide and low oxygen atmospheres. Proc. Amer. Soc. Hort. Sci. 86:347-356.

Lipton, W.J. 1968. Market quality of asparagusEffects of maturity at harvest and of high carbon dioxide atmospheres during simulated transit. U.S. Dept. Agr. Mktg. Res. Rpt. no. 817.

Lougheed, E.C. and D.H. Dewey. 1966. Factors affecting the tenderizing effect of modified atmospheres on asparagus spears during storage. Proc. Amer. Soc. Hort. Sci. 89:336-345.

Wang, S.S., N.F. Haard, and G.R. DiMarco. 1971. Chlorophyll degradation during CA storage of asparagus. J. Food Sci. 36:657-661.

Weichmann, J. 1986. The effects of controlledatmosphere storage on the sensory and nutritional quality of fruits and vegetables. Hort. Rev. 8:101-127.

Yemm, E.Y. and E.C. Cocking. 1955. The determination of amino acids with ninhydrin. Analyst 80:209-213. 